\title{
THE STATUS OF LOONS IN IDAHO
}

\author{
DANIEL M. TAYLOR, 3115 S.E. 8th Ave., Portland, Oregon 97209
}

\begin{abstract}
This report summarizes and updates the population status and distribution of loons in Idaho. Formerly, the Common Loon bred in northern, central, and southeastern Idaho, probably widely. With only sporadic unsustained nesting in the last half century it has been essentially extirpated as a breeding species, but flocks of up to 200 migrating birds occur in spring and autumn. In spring, concentrations are most frequent in southeastern and south-central Idaho, but in autumn they are widespread. Common Loon migration peaks from mid-April to early May and from mid-October to mid-November. The species winters in numbers of up to 20 on large lakes in northern and southwestern Idaho. The Pacific Loon was not conclusively recorded in Idaho before 1974, but since the mid-1980s a few to dozens have occurred annually in autumn throughout the state, with concentrations of up to 30. Its autumn migration peaks from mid-October to late November. In most years a few now winter, primarily in northern Idaho. There have been a dozen spring and three summer records. Early in the $20^{\text {th }}$ century the Red-throated Loon was recorded rarely in migration but since the 1980s it has been recorded most years, most frequently in autumn. First noted in 1979, the Yellow-billed Loon remains rare. In spring, summer, and winter it is recorded principally from large lakes in northern Idaho, but autumn records are widespread.
\end{abstract}

In Idaho, loons have received very little attention from ornithologists. The major works on Idaho birds (Larrison et al. 1967:63, Burleigh 1972:1) provide only anecdotal information, with no specific nesting records of the Common Loon (Gavia immer) and no records for two other species now known to occur in the state. The Common Loon is considered a "species of greatest conservation need tier 2" and "critically imperiled breeding/imperiled nonbreeding" by the Idaho Department of Fish and Game (IDFG 2017), and a "sensitive species" in the U.S. Forest Service's intermountain and northern regions (IDFG 2005, 2019). The paucity of information and precarious status calls for a synthesis of data on the breeding status, population dynamics, chronology, and distribution of loons in Idaho. This report summarizes what is known about nesting Common Loons in the state, and the abundance, distribution, and seasonal occurrence of all loon species occurring in Idaho.

\section{STUDY AREA AND METHODS}

I attempted to gather and evaluate all information about loons in Idaho. My literature review for Idaho and the adjacent states included the relevant seasonal reports in American Birds (AB), National Audubon Society Field Notes (NASFN), and North American Birds (NAB) from 1961 to 2018, as well as the results of Christmas Bird Counts (CBC) from 1954 to 2018. I compiled data from the Sturts Idaho Bird Records Database (https://ibrc.idahobirds. net/idaho-bird-records-database) and the reports endorsed by the Idaho Bird Record Committee (IBRC; https://ibrc.idahobirds.net/rare-bird-reports), which has reviewed many of the reports of the Red-throated (G. stellata) and Yellow-billed (G. adamsii) Loons and summer reports of the Pacific Loon ( $G$. pacifica). All specific reports of these loon species not in the main text are listed in Appendix 1, available at https://archive.westernfieldornithologists.org/ 
archive/V52/Taylor-loons.pdf. I contacted biologists monitoring or studying loons in Idaho and adjacent states, including those associated with state and federal agencies, the Biodiversity Research Institute, and the Greater Yellowstone Loon Working Group. I used Google Earth Pro to map the Common Loon's reported nesting sites and seasonal concentrations, the latter based on maximum numbers reported at various sites (Appendix 1). The graphs of seasonal abundance of the Common and Pacific Loons are based on records entered at www.eBird.org through February 2019. For these I went to the "species map" tab for the species, setting the date as March-May or AugustNovember, bringing up all reports for the period, and compiling the number of loons at each site by date. When there were multiple reports on the same date at a "hotspot" and nearby points, I recorded only the highest count at the site for that date. I then tallied all individual counts for each date and plotted them with GraphPad Prism8 (www.graphpad.com).

\section{RESULTS}

\section{Breeding/Summer Status of the Common Loon}

In the past, Common Loons bred in northern and central Idaho and likely along the the state's southeastern edge (Figure 1, Appendix 1). Owing to the

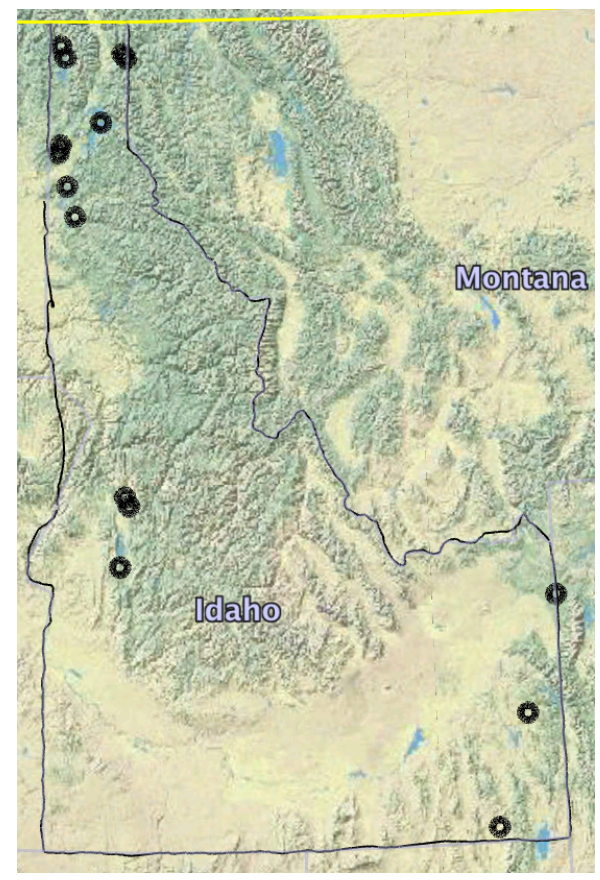

FIgURE 1. Locations of recorded breeding of the Common Loon in Idaho. See Appendix 1 for sources. 


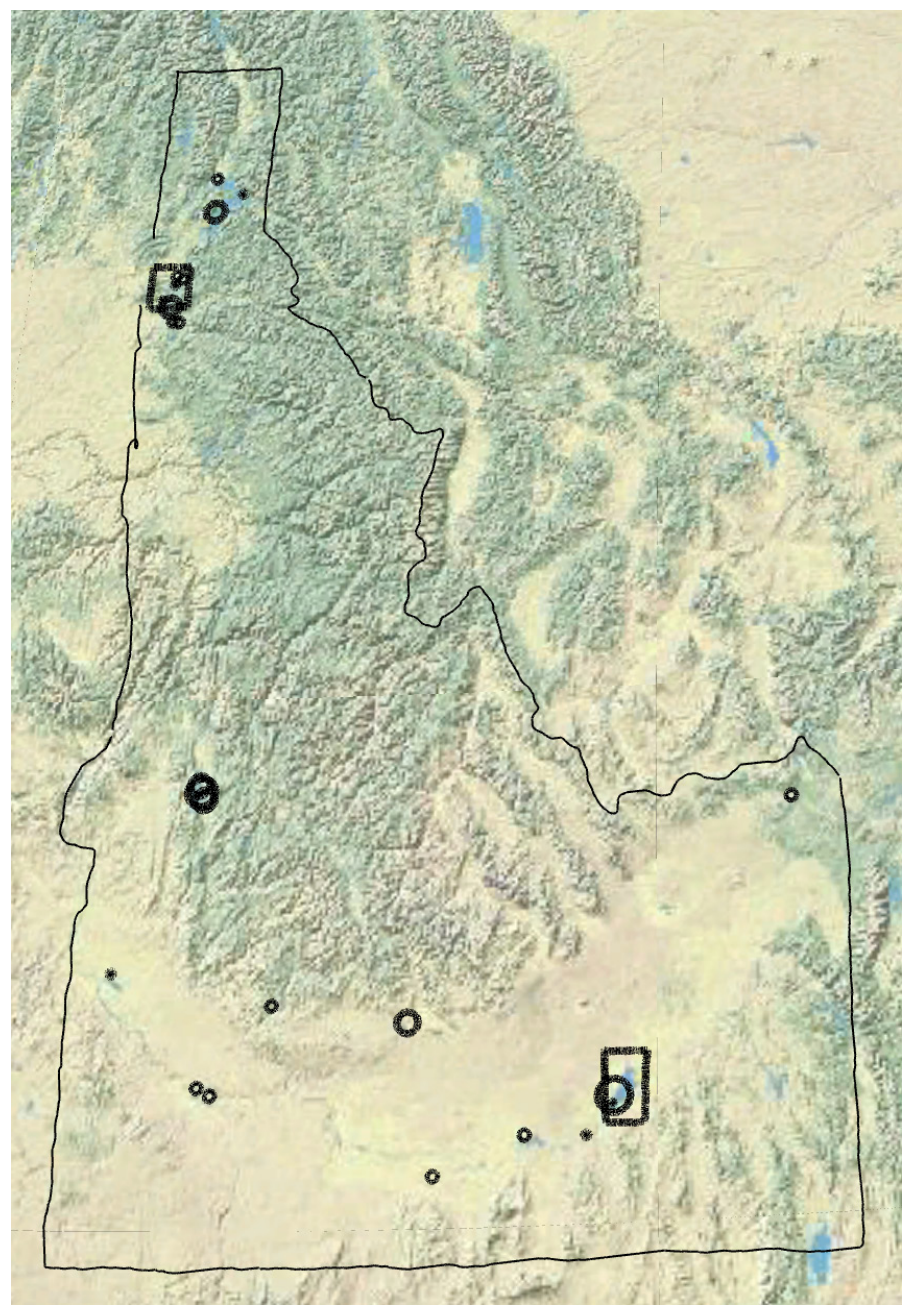

FIgURE 2. Locations of concentrations of the Common Loon in Idaho, AugustNovember, by five categories of numbers. Smallest solid dot, 11-20; smallest circle with opening, 21-50; second smallest circle with opening, 51-100; biggest circle with opening, 100-130; square in north, peak of 166; rectangle in south, peak of 212 . See Appendix 1 for sources.

woeful history of early Idaho ornithology, the historical status of nesting loons in Idaho is opaque. At the end of the $19^{\text {th }}$ century Merrill (1897) found the species common and nesting at Lake Coeur d'Alene, and Tyro (1894) described an adult with young at Priest Lake and courting loons at nearby Blue Lake in northern Idaho. Neither Larrison et al. (1967:63) nor Burleigh (1972:1) listed any specific records of nests, but both authors cited nesting 
in parts of northern, central, and potentially southern Idaho (Figure 1, Appendix 1). The Common Loon was observed and collected in summer in southeastern Idaho in the early $20^{\text {th }}$ century (Rust 1917, Taylor et al. 1997). In 1985 and 1986, Fitch and Trost (1985 and C. H. Trost pers. comm.) surveyed 155 lakes throughout Idaho with potential habitat for nesting loons. They observed territorial behavior at Lake Pend Oreille and Cascade Reservoir but did not find any active nests or young. Evers et al. (2010) concluded that the Common Loon had been extirpated from Idaho by the mid-20th century. Any reports on Breeding Bird Surveys from 1966 to 2015 were insufficient for Sauer et al. (2017) to report a trend line for the Common Loon in Idaho. Since the 1980s occasional pairs of loons have nested sporadically for one or a few years in northern, central, and southeastern Idaho (specific records in Appendix 1), but no consistent populations are established, and the species remains effectively extirpated.

Nonbreeding Common Loons, often immatures, occur infrequently in the summer. Fitch and Trost's (1985) survey of 155 lakes yielded a total of 33 birds, most in northern and southeastern Idaho. Taylor et al. (1999) recorded up to six at American Falls Reservoir, June-July. The $\sim 35$ reports via eBird during these two months, of one or two birds, are scattered throughout the state but concentrated at Island Park Reservoir and Henry's Lake.

\section{Status of the Common Loon Outside the Breeding Season}

Autumn. Larrison et al. (1967) considered the Common Loon a regular migrant during October in the north, less so in the south. Burleigh (1972) stated it was a fairly common transient with most records from October, but neither quantified numbers. Hand (1941) considered it common on lakes in northern Idaho, and recorded 9 on Fish Lake 28 October 1928 (Hand 1932). The Common Loon is now known to be a common migrant throughout the state with the largest concentrations on the biggest lakes and reservoirs (Figure 2, Appendix 1). A tally by date of all reports to eBird from August to November shows numbers are very low from August to mid-September, then increase to a peak from mid-October to mid-November (Figure 3).

Winter. Larrison et al. (1967:63) and Burleigh (1972:1) considered the Common Loon to winter in Idaho rarely or in small numbers. The winter reports published in North American Birds, etc., from 1961 to 2017 contain few specific records of the Common Loon. Approximately 20 in winter 1997-1998 was a number higher than normal (NASFN 52:227). December-February reports to eBird are concentrated around Lake Pend Oreille, Coeur d'Alene Lake, and the Snake River near Lewiston in northern Idaho, and C. J. Strike Reservoir and Lake Lowell in southwestern Idaho. Lying at lower elevations, these are large bodies of water that tend to stay ice free much or all of the winter. Lake Pend Oreille had by far the highest concentrations with counts $\geq 10$ in 4 years and a maximum of 20 on 12 December 2008 (Sturts; T. Little and J. Isacoft, eBird). Except for Coeur d'Alene Lake (5 in December 2014; S. Joyce, eBird), no other site had more than 3.

CBCs for all of Idaho from 1955 to 1988 found 1-3 loons in about onethird of the years, with the exception of 13 loons in 1963 (of which 11 were on the Nampa CBC). From 1989 to 2017 , loons occurred every year, with a mean of 9.2 per year and a peak of 29 in 2012 . This increase coincided with the ini- 


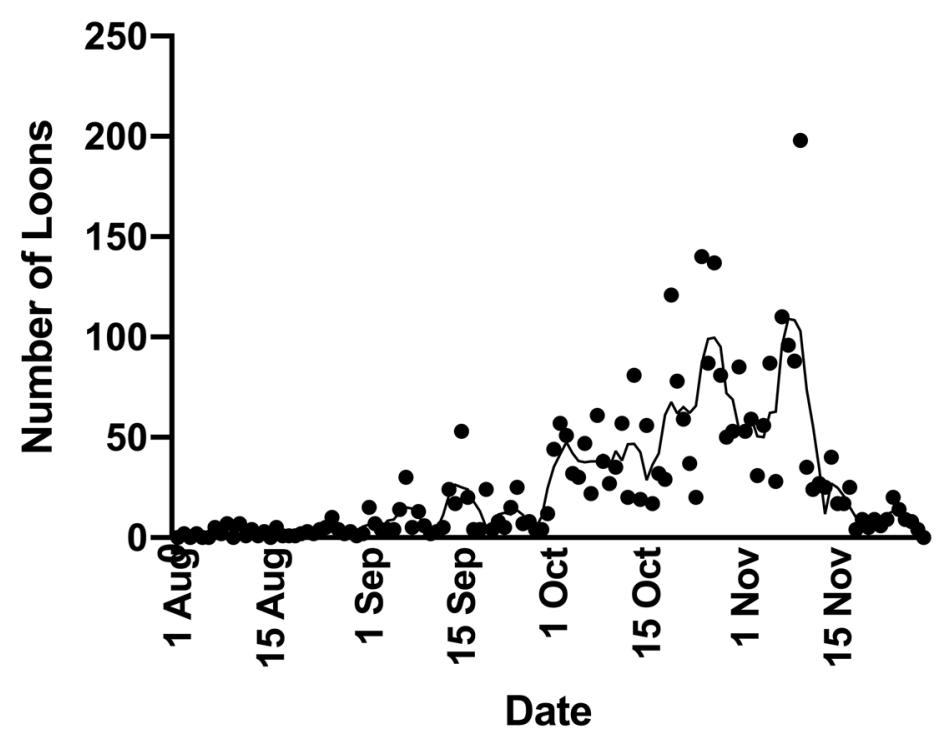

FIgURE 3. Temporal pattern of Idaho reports of the Common Loon to www.eBird.org, August-November, for all years through 2018. Each dot represents the total number of loons recorded on that date from all hot spots and sites. The trend line is derived by second-order smoothing of four neighboring dots.

tiation of the Spirit Lake, Sandpoint, and Bruneau CBCs, which incorporated sections of Pend Oreille and Coeur d'Alene lakes and C. J. Strike Reservoir. These three CBCs accounted for 174 (65\%) of the 266 loons counted during this time. Thus small numbers of Common Loons winter consistently in Idaho, occurring primarily on large lakes and reservoirs at lower elevations and on sections of the Snake River in northern and southwestern Idaho.

Spring. Until late in the 20th century, the Common Loon was reported as regular but occurring in only low numbers. Larrison et al. (1967:63) found it a "regular migrant (only a few individuals) on northern lakes; less regular in south, (regular on Island Park Reservoir, Henry and Gray's Lake)," occurring in April, while Burleigh (1972:1) listed a few scattered March to mid-May records from across the state. The only large numbers recorded during the 1960s and 1970s were 20 at Lake Lowell and 15 by American Falls Dam in 1976 (AB 30:866). In the 1980s and 1990s large numbers were reported only from Benewah Lake in northern Idaho (up to 20; Sturts) and Twin Lakes Reservoir in southeastern Idaho (peak counts of 150, 100, 80, and 72 from 1987 to 1991; AB 41:463, AB 42:464, AB 44:446, AB 45:474). During this time, the reservoir was closed to fishing until late spring (journals of $\mathrm{C}$. $\mathrm{H}$. Trost). Increasing observations over the last half century now show the Common Loon to be a widespread migrant throughout the state on big and small lakes, rivers, and reservoirs from March to May (Appendix 1). Large groups of loons have been found most commonly in south-central and southeastern 
Idaho, much less so in central, southwestern, and northern Idaho (Figure 4, Appendix 1), despite birders' activity in the former areas being much lower. The rate of reports to eBird accelerates rapidly from mid-March to a peak from mid-April to early May (Figure 5).

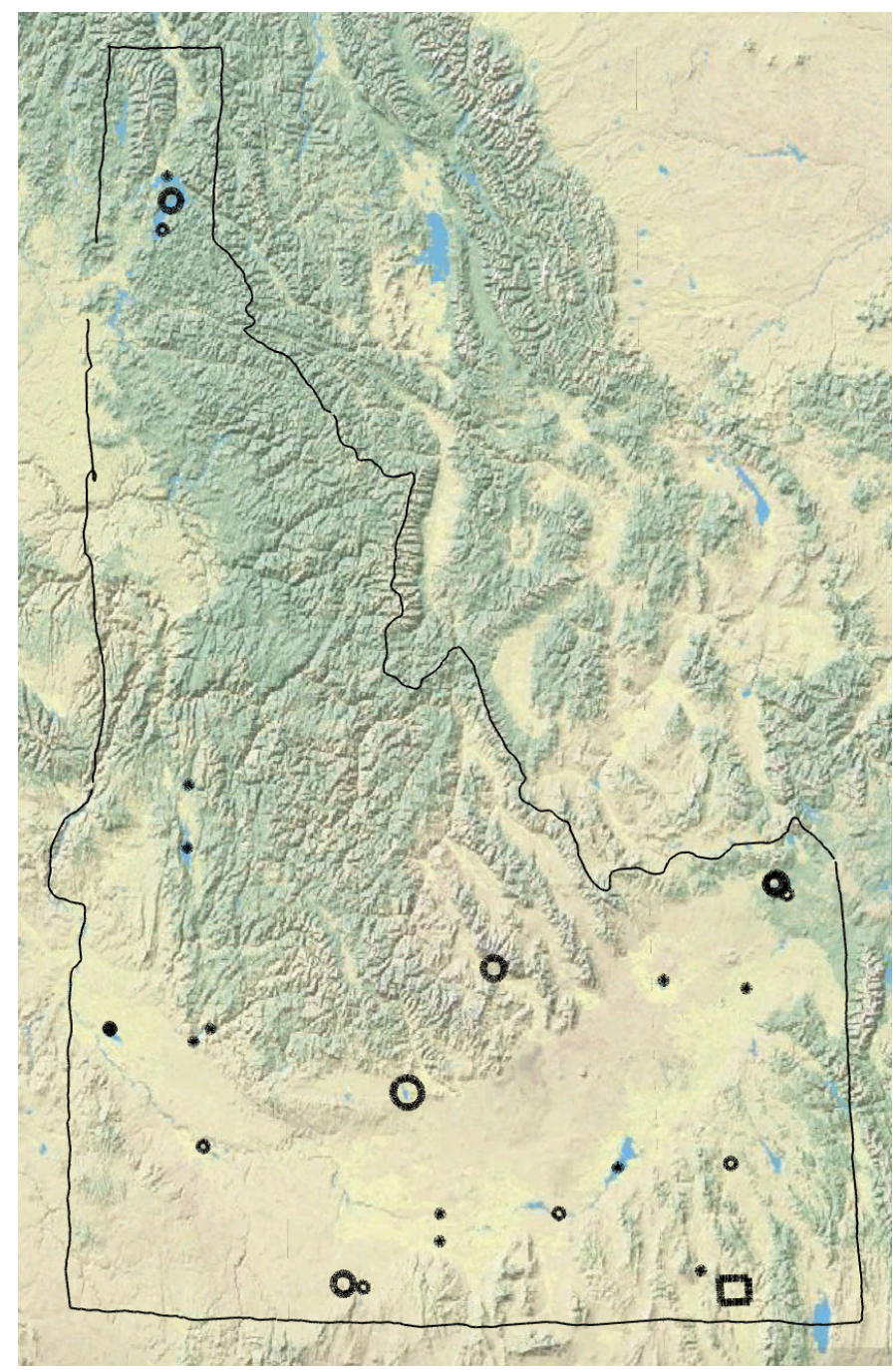

FIgURE 4. Locations of concentrations of the Common Loon in Idaho, March-May, by five categories of numbers. Smallest solid dot, 11-20; smallest circle with opening, 21-50; second smallest circle with opening, 51-100; biggest circle with opening, 100-110; rectangle, peak of 150. See Appendix 1 for sources. 


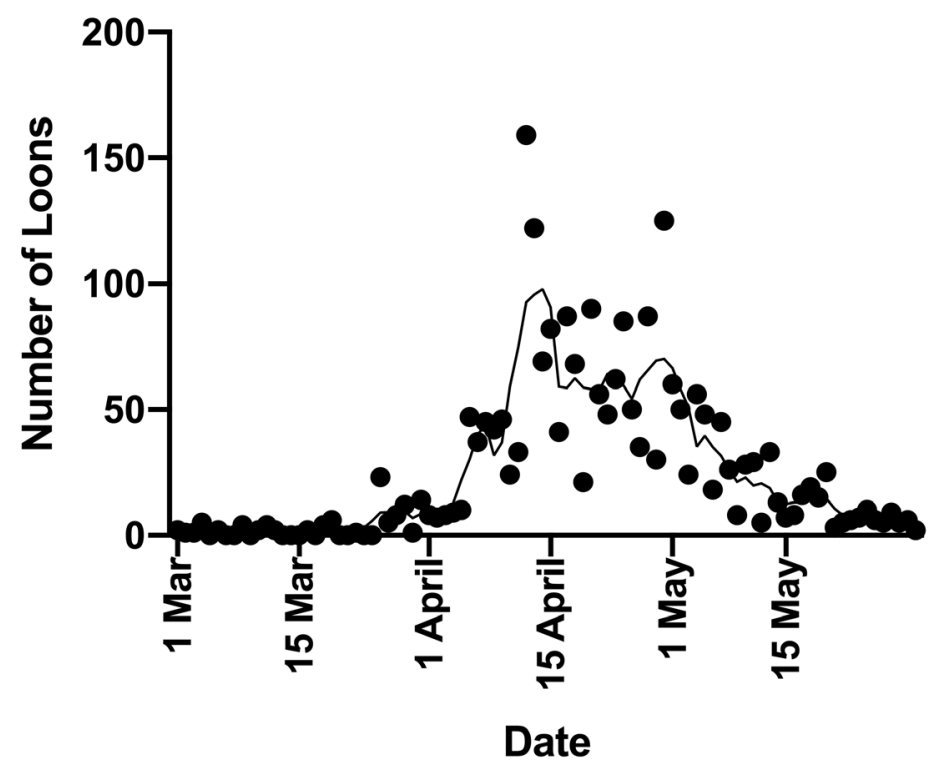

FIgURE 5. Temporal pattern of Idaho reports of the Common Loon to www.eBird.org, March-May, for all years through 2018. Each dot represents the total number of loons recorded on that date from all hot spots and sites. The trend line is derived by secondorder smoothing of four neighboring dots.

\section{Pacific Loon}

Autumn. The Pacific Loon was first recorded definitively in Idaho on 3 November 1975 when D. Woodby collected a specimen near Viola, Latah Co. (Weber 1978). By 1985 there were but 12 state records, all from between 20 October and 8 December (Taylor and Trost 1987). Autumn sightings increased rapidly starting in 1986 with reports of a few to dozens almost every year and a maximum concentration of 30 (Appendix 1). Autumn reports via eBird, totaling 174 individuals, imply arrival in late September and peak migration from mid-October to mid-November (Figure 6). The Pacific Loon occurs primarily on the same large lakes and reservoirs as the Common Loon, including Pend Oreille, Coeur d' Alene, Cascade, Lowell, C. J. Strike, American Falls, and Island Park, but also occasionally on smaller bodies of still water and the Snake River.

Winter. The Pacific Loon was first noted in Idaho, though without published support, on the Sandpoint CBC in 1954 (Sturts). Thirty-two years would elapse before the next winter record, this from Hayden Lake 2-9 January 1986 (AB 41:305). Subsequently, the Pacific Loon has been recorded most winters. The $>30$ additional records are mostly from northern Idaho with a few in the southwestern part of the state and one each in south-central and southeastern Idaho (Appendix 1).

Spring. Through the mid-1980s there were no spring records (Taylor and 


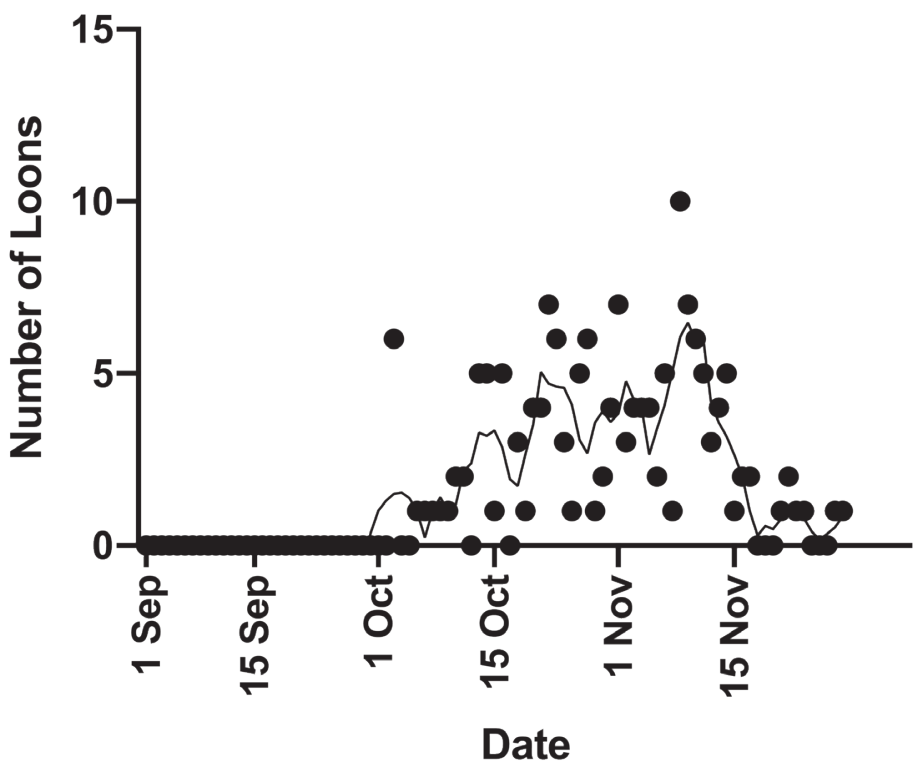

Figure 6. Temporal pattern of Idaho reports of the Pacific Loon to www.eBird.org, August-November, for all years through 2018. Each dot represents the total number of loons recorded on that date from all hot spots and sites. The trend line is derived by second-order smoothing of four neighboring dots.

Trost 1987), but since 1990, 11 records from 4 March to 21 May have accumulated, of which 7 are from northern Idaho (Appendix 1).

Summer. Single individuals have been recorded at lakes Pend Oreille (16 June 2001; C. Swift, eBird) and Coeur d'Alene (4 June 2013; Idaho Survey of the Intermountain Bird Observatory, eBird) in northern Idaho and Daniel's Reservoir in southeastern Idaho (18 June 2020, pers. obs.).

\section{Red-throated Loon}

Autumn: The first report of a Red-throated Loon in Idaho was based on a specimen from Coeur d'Alene examined by Rust (1913) on 12 October 1912 but apparently not preserved. There are two records from the 1970s (AB 29:89, $\mathrm{AB}$ 30:91), and since 1980 the species has been recorded almost annually, beginning in August (Appendix 1). Most records are from northern Idaho, especially Coeur d'Alene Lake, but records are scattered throughout the state.

Winter: Red-throated Loons have rarely occurred in this season. Three northern Idaho records are from Hayden Lake (AB 41:305; AB 42:297; AB 44:296) and another is from Coeur d'Alene Lake (NASFN 48:208). In southwestern Idaho two were at Lake Lowell near Nampa through the winter of 1975-76 (AB 30:742) and one was at C. J. Strike Reservoir through the winter of 2010-11 (many obs., eBird).

Spring: From 1919 to 1921 birds were recorded around Minidoka 5 sepa- 
rate times from 14 April to 20 May (Davis 1935), but only 4 more times in the ensuing century. The subsequent spring records are of single individuals near Moscow in May 1982 ("no details supplied," AB 36:875), on Hayden Lake, 20 March 1990 (AB 44:446), and on Lake Pend Oreille, 14-16 April 2007 (NAB 61:483) in northern Idaho and near American Falls Reservoir, 2-3 May 1999 (NAB 53:304) in southeastern Idaho.

Summer: In northern Idaho summering Red-throated Loons were recorded at Hayden Lake 17-21 June 1981 and McArthur Lake Wildlife Management Area on 28 June 1982 (IBRC).

\section{Yellow-billed Loon}

Since the first report in 1979 (AB 34:182), one or a few have been reported many years. About half the sightings have been submitted to the IBRC, with 9 of 11 accepted. Winter and spring records are primarily from the northern lakes Pend Oreille and Coeur d'Alene, but a few records are from southcentral and southeastern Idaho. Autumn records come from southern Idaho and Lake Pend Oreille. The only summer records are of immature birds at Coeur d'Alene Lake on 16 June 2004 (NAB 58:566) and 5 July 2020 (IBRC rare bird report 2020-B-28).

\section{DISCUSSION}

The evidence suggests that Common Loons formerly bred on lakes in northern, central, and southeastern Idaho, probably widely, but have been essentially extirpated. Sporadic nesting may have also occurred on reservoirs in south-central and southwestern Idaho. Gap analysis indicates suitable nesting habitat remains in these regions of Idaho (Scott et al. 2002). Nesting loon populations are present in adjacent northwestern Montana (Marks et al. 2016, p. 127), the Greater Yellowstone Ecosystem (V. Spagnuolo pers. comm.), and eastern Washington (Savoy et al. 2019), where a pair nested very close to Idaho in 1925 (Ransom 1929). Hunting, disturbance by human activities, and lead poisoning have been considered possible reasons for this decline (IDFG 2017, V. Spagnuolo pers. comm.). The population trend for the Common Loon on the Breeding Bird Surveys in the Northern Rockies Region is positive, but variation is wide and the credible intervals for the trend estimates straddle zero (Sauer et al. 2017). Efforts to re-establish breeding loon populations have met with some success in Montana, Wyoming, and eastern Washington (Marks et al. 2016, Savoy et al. 2019, V. Spagnuolo pers. comm.). Artificial nesting platforms were placed in Upper Priest, Priest, Pend Oreille, and Coeur d'Alene lakes in northern Idaho as part of the Idaho Bird Inventory and Survey (IBIS) program (IDFG 2005), but without apparent success. There have been no regular surveys there for over 10 years (C. Moulton pers. comm.). Most recent Idaho nests have been found on small isolated lakes (Blue, Thompson Hole, Indian, Bonner) with less human disturbance, suggesting that such disturbance on larger popular lakes is a factor in precluding re-establishment.

The much greater concentration of Common Loons in southeastern and south-central Idaho indicates that these areas are on the main route of the mid-continental breeding populations that cross the Rocky Mountains during spring migration (Evers et. al 2010). In contrast to spring, the larger autumn 
concentrations in northern Idaho suggest that the region's large natural lakes are staging sites for loons moving from nesting areas farther north. Many of the reservoirs in southern Idaho, especially small ones, are often severely drawn down by autumn and provide limited habitat for loons at this time. In both seasons of migration, systematic censusing of key bodies of water, especially in northern, south-central, and southeastern Idaho would clarify their value to migrating loons.

Records of all loon species in Idaho have increased as bird watchers and forums for recording observations have increased. The relative increases of the Common, Red-throated, and Yellow-billed Loons are generally consistent with the increase of effort. Rarely recorded in the early $20^{\text {th }}$ century, the Red-throated has been found increasingly but only in modest numbers, and it remains surprisingly rare in spring by comparison to early records. The lack of any Yellow-billed Loon records before 1979 probably reflects that species' continuing rarity in Idaho and as well as spotty observer coverage in earlier eras. The dramatic increase of the Pacific Loon since 1980 and near absence of any records before is more enigmatic. The Pacific Loon is not difficult to distinguish. Northern Idaho had Merrill (1897) observing for a few years at Coeur d'Alene Lake, and eminent ornithologists R. L. Hand, E. J. Larrison, and T. D. Burleigh spent decades in this region without recording the species. Southern Idaho suffered from a dearth of observers for much of the $20^{\text {th }}$ century, but C. H. Trost has birded very actively in southeastern Idaho since 1968. It seems remarkable that none recorded a single Pacific Loon if there had been no change in its frequency of occurrence in the state. One possible factor causing this change has been a large increase in the number of reservoirs over time, especially in southern Idaho. Loons use these reservoirs heavily, and their construction in Idaho and adjacent states has probably facilitated loons' migration through this region.

\section{ACKNOWLEDGMENTS}

Tiffany Grade, James Paruk, Vincent Spagnuolo, Colleen Moulton, and Rita Dixon all provided useful information for this paper. I thank Charles $\mathrm{H}$. Trost for his gracious access to his extensive field notes and commentary and Daniel R. Reinking and Robert E. Gill Jr. for extensive editing and commentary.

\section{LITERATURE CITED}

Burleigh, T. D. 1972. Birds of Idaho. Caxton Printers, Caldwell, ID.

Davis, W. B. 1935. An analysis of the bird population in the vicinity of Rupert, Idaho. Condor 37:233-238; doi.org/10.2307/1363729.

Evers, D. C., Paruk, J. D., McIntyre, J. W., and Barr, J. F. 2010. Common Loon (Gavia immer), in The Birds of North America (P. G. Rodewald, ed.), no. 313, version 2.0. Cornell Lab Ornithol., Ithaca, NY; doi.org/10.2173/bna.313.

Fitch, T., and Trost, C. H. 1985. Nesting status of the Common Loon in Idaho in 1985. Report to the Idaho Natural Heritage Program, Ida. Dept. Fish and Game, Boise.

Hand, R. L. 1932. Notes on the occurrence of water and shore birds in the Lochsa region of Idaho. Condor 34:23-25; doi.org/10.2307/1363788.

Hand, R. L. 1941. Birds of St. Joe National Forest, Idaho. Condor 43:220-232; doi. org/10.2307/1364504. 
Idaho Fish and Game. 2005. Common Loon Gavia immer; https://idfg.idaho.gov/ ifwis/cwcs/pdf/Common\%20Loon.pdf (accessed January 2019).

Idaho Fish and Game. 2017. Common Loon, in Idaho State Wildlife Action Plan 2015. Appendix F. Species conservation status assessments, pp. 981-982; https:// idfg.idaho.gov/sites/default/files/state-wildlife-action-plan.pdf.

Idaho Fish and Game 2019. Common Loon. Idaho species; https://idfg.idaho.gov/ species/taxa/15698 (accessed 14 February 2019).

Larrison, E. J., Tucker, J .L., and Jollie, M. T. 1967. Guide to Idaho birds. J. Ida. Acad. Sci. 5:1-220.

Marks, J. S., Hendricks, P., and Casey, D. 2016. Birds of Montana. Buteo Books, Arrington, VA.

Merrill, J. C. 1897. Notes on the birds of Fort Sherman, Idaho. Auk 14:347-357; doi. org/10.2307/4068468.

Ransom, W. H. 1929. Miscellaneous avifaunal observations, No. 1. Murrelet 10:3437; doi.org/10.2307/3534077.

Rust, H. J. 1913. Birds new to the vicinity of Lake Coeur d'Alene, Kootenai County, Idaho. Condor 15:41.

Rust, H. J. 1917. An annotated list of the birds of Fremont County, Idaho, as observed in the summer of 1916. Condor 19:29-43; doi.org/10.2307/1362639.

Sauer, J. R., Niven, D. K., Hines, J. E., Ziolkowski, D. J. Jr., Pardieck, K. L., Fallow, J. E., and Link, W. A. 2017. The North American Breeding Bird Survey, results and analysis 1966-2015, version 2.07.2017. USGS Patuxent Wildlife Research Center, Laurel, MD; https://www.mbr-pwrc.usgs.gov/bbs/bbs.html.

Savoy, L., Poleschook, D., Poleschook, V., and Evers, D. C. 2019. Washington status report for the Common Loon. Biodiv. Res. Inst., Portland, Maine. Science Communications Series BRI 2020-11.

Scott, J. M., Peterson, C. R., Karl, J. W., Strand, E., Svancara, L. K., and Wright, N. M. 2002. A gap analysis of Idaho: Final report. Idaho Coop. Fish and Wildlife Res. Unit, Moscow.

Taylor, D. M., and Trost, C. H. 1987. The status of rare birds in Idaho. Murrelet 68:69-93; doi.org/10.2307/3534113.

Taylor, D. M., Trost, C. H., Jones, V. E., and Fichter, E. 1997. Bird specimens from Idaho in the Idaho Museum of Natural History. Tebiwa 26:255-287.

Taylor, D. M., Burrup, D., Trost, C. H., and Porth, A. 1999. Birds of the American Falls Reservoir area, Snake River, Idaho. J. Idaho Acad. Sci. 35:1-37.

Tyro. 1894. Some queer habits of Urinator imber. Oologist 11:364-366.

Weber, J. W. 1978. First Idaho records of the Arctic Loon and its history east of the Cascades in Oregon and Washington. Murrelet 59:109-100.

Accepted 3 October 2020 